\title{
AN EVALUATION OF THE FACILITATORS OF TRUSTWORTHINESS
}

\author{
NEVILLE BEWS \\ Department of Sociology \\ Rand Afrikaans University \\ NICO MARTINS \\ Department of Industrial Psychology \\ University of South Africa
}

\begin{abstract}
Recent changes in the nature of work initiated by the emerging "post-industrial" society have rekindled a multidisciplinary interest in trust. In view of these developments the issue of intra-organisational trust is addressed in terms of a model of trust. The validity of an aspect of this model, in respect of the proposed facilitators of trustworthiness, is empirically tested in a South African financial institution. Results of this test are then compared with the results of a similar and recent study also undertaken in a South Africa context.
\end{abstract}

\section{OPSOMMING}

Onlangse veranderinge in die aard van werk wat voortspruit uit die opkomende nywerheidwese, het ' $n$ multidissiplinêre belangstelling in vertroue tot gevolg gehad. In die lig hiervan is die kwessie van 'n interdissiplinêre vertroue as model vir vertroue ondersoek. Die geldigheid, as oogmerk van hierdie model ten opsigte van die voorgenome aanbieders van vertrouenswaardighed, is aan ' $n$ proefondervindinglike toets onderwerp in ' $n$ SuidAfrikaanse finansiële instelling. Die uitslae van hierdie toets word vergelyk met die resultate van ' $n$ soortgelyke onlangse studie wat ook in Suid-Afrikaanse verband onderneem is.

With the emergence of what some have labelled the post-industrial or information age (Bell, 1973; Masuda, 1981), the nature of work has undergone considerable change as organisations restructure in an attempt to cope with the emerging new order (Howard, 1996). These changes have created a greater demand for project teams, temporary work groups, networking and organisational flexibility (Handy, 1994), thus emphasising the need for trust-based relationships (Crandall \& Wallace, 1998; Dibben, 2000). This emphasis comes at a time when job security continues to decrease and promotional opportunities continue to shrink, placing trustbased relationships in crisis as the intra-organisational trust-gap widens (Hiltrop, 1995; Horton \& Reid, 1996).

The unfolding of these events has caught the notice of numerous academics, with trust receiving the attention of social management and behavioural scientists (Engelbrecht \& Cloete, 2000; Horton \& Reid, 1996; Kramer, \& Tyler, 1996; Martins, 2000; and Mayer, Davis, \& Schoorman, 1995, amongst others). In a 1995 American Management Association survey, organisational team members ranked "interpersonal trust" first among eight desired changes in the workplace (Kreitner \& Kinichi, 1998). Philosophers, have also taken note of this renewed emphasis on trust, particularly in respect of business ethics, and some have warned against an overemphasis on trust-based relationships and reminded us of the limits of trust (Brenkert, 1998a; 1998b; Darley, 1998; Flores \& Solomon, 1998; Husted, 1998 and Jones \& Bowie, 1998).

Although trust has received all this attention, little has emerged in respect of a theory of trust. However, towards this end, Mayer et al. (1995) suggested an "Integrated Model of Interpersonal Trust" and Engelbrecht and Cloete (2000) have tested this model, finding support for it in certain areas. Building on the work of Mayer (2000) amongst others (Lewicki \& Bunker, 1996; Martins, 2000, 1997; Meyerson, Weick, \& Kramer, 1996; Mishra, 1996), Bews (1999) proposed an integrated model for intra-organisational trust. Aspects of this model were empirically tested and, in some respects, show congruence with Engelbrecht and Cloete's (2000) findings in respect of the model of Mayer et al. In this article, this model will be briefly described and the results of aspects of the empirical tests that were applied will be reported on.

Requests for copies should be addressed to: $N$ Martins, Department of Industrial Psychology, UNISA, PO Box 392, UNISA, 0003.E-mail: martin@unisa.ac.za, bewsco@netactive.co.za

\section{Defining trust}

Trust is not a phenomenon that can be defined in simple terms as a great deal of confusion surrounds it. The notion of risk is, for instance, an important factor in defining trust (Lewicki \& Bunker, 1996; Mayer et al., 1995; Mishra, 1996; and Sheppard \& Tuchinsky, 1996). In this respect, Mayer et al. (1995, p. 724) distinguish between willingness to trust and trusting behaviour, arguing that " ...risk is inherent in the behavioural manifestation of the willingness to be vulnerable" rather than merely in the willingness to trust. Brenkert (1998b) makes a distinction between trust and trustworthiness, namely that whereas trust is an attitude, trustworthiness is an evaluative appraisal. Flores and Solomons (1998, p. 212) suggest that since trust is created through social interaction, it can, and should, be learned as a social skill "...essential to our emotional well-being." Soule (1998, p. 262-263) proposes that trust is deeper than confidence, co-operation and reliance and that it implies vulnerability. Martins (2000) suggests that the definitions of trust that were investigated, indicate that trust appears to be a dynamic phenomenon that depends on the interplay of various factors that might affect the building of a model of trust.

Consequently, for our purposes, and on an interpersonal level, trust is defined as "a voluntary action of one party, flowing from an evaluation, based on the social skills of that party, concerning the potential of another, or others, not to take advantage of the vulnerability of the first party." (Bews, 2000, p. 19). This now leads us to a consideration of the dynamics of trust.

\section{Aspects of a model of trust}

It is proposed, as illustrated in figure 1 , that trust is a dynamic phenomenon that unfolds over two sequential stages, both of which depend on the interplay of various factors. The first of these stages is directional, depends on certain pre-trust conditions, and is usually short in duration. The second is variable, depends on perceptions in respect of the facilitators of trustworthiness, and continues throughout the duration of the relationship. While the pre-trust conditions concern such issues as the contextual factors, perceived risk, propensity to trust and reputation, the facilitators of trustworthiness include benevolence, competency, integrity, personality characteristics, a history of interactions and openness. 
Figure 1: STAgeS OF TRUST FORMATION

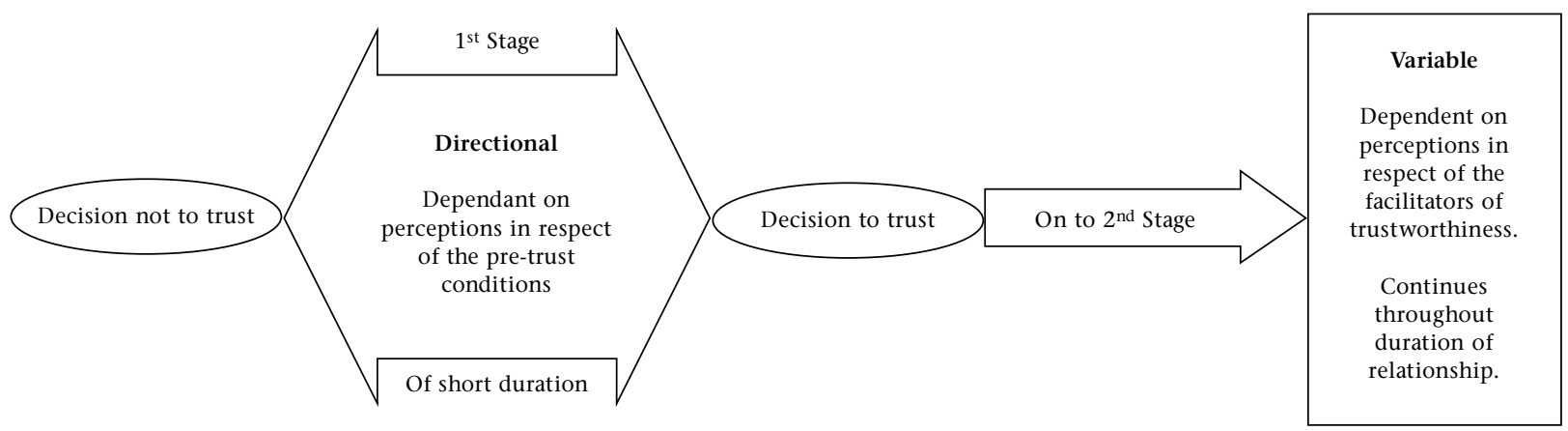

Contextual factors relate to alternatives available to the trustor, in respect of power relationships and the stakes involved, that influence the degree of freedom that governs the trustor's decision to embark, or not to embark, on a particular trustbased relationship. For instance, during times of high unemployment the contextual factors may be of such a nature that they leave the trustor little choice but to enter a trust-based relationship. In certain extreme cases this may even result in the formation of a faked form of trust that could be referred to as "spurious trust". The trustor may have avoided a relationship based on "spurious trust", at times of greater job opportunity or, in broader terms, during times of greater choice. For example A may not trust B yet may be forced, because of the contextual factors, to at least sham trust. For example A may be unemployed and, having no income in an environment of few job opportunities, may decide, in an attempt to secure employment, to act in a manner that causes B to believe that $\mathrm{A}$ trusts B. Even at this level, trust has the potential to escalate once the facilitators of trustworthiness are appropriate.

Perceived risk concerns the amount of potential damage that the trustor perceives she may suffer compared with the value that she believes she will gain from the relationship. In situations where the potential for damage is high, the trustor may seek to minimise this risk and may rely on other pre-trust conditions, such as reputation, before deciding to engage in a trust-based relationship. For example, a patient may be inclined to investigate the surgeon's credentials before undergoing open heart surgery and may even get a second opinion.

Propensity to trust refers to certain internalised factors such as individual "make-up", which may include cultural background, personality characteristics (Mayer et al., 1995), social setting (Creed \& Miles, 1996) and a history of interactions or experiences (Lewicki \& Bunker, 1996). All of these are contained in the trustor's stock of knowledge and may influence the trustor's inclination to embark on a trust-based relationship. Propensity to trust may be lubricated by a degree of familiarity although too great a degree of familiarity also has its dangers. Powell (1996), for instance, highlights the importance of kinship and professional communities and the common association that led to co-operation in the "Third Italy" and Baden-Württemberg, Germany, while Husted (1998) cautions against the favouritism that familiarity could lead to and that may erode the morality of trust.

Reputation refers to the gathering of a stock of knowledge against which the trustor is able to evaluate the trustee's potential to act in a trusting manner. Knowledge gathered in this way is largely based on observations and third-party interventions and may also depend on first-hand experiences, although to a somewhat lesser degree prior to the formation of a relationship. Regarding third-party intervention, Burt and Knez (1996) alert us to the role of "third-party gossip" and, in so doing, make a distinction between "full-disclosure" and "partial-disclosure gossip". "Full-disclosure gossip" refers to full and accurate accounts of the actions of alter, while "partial- disclosure gossip" refers to incomplete reports of these actions. In this way the trustor evaluates the trustee's reputation, using this information, along with that gathered in respect of other pre-trust conditions, as a basis on which to either form or avoid a particular trust-based relationship.

Meyerson, Weick and Kramer (1996) point out that reputation plays an important role in the formation of "swift trust", a form of trust required for the rapid formation of project teams. In this regard, Jones and Bowie (1998) warn against the effects of relying overly much on reputation and refer to "false-negative" and "false-positive" information that, if not verified over time, may distort reputation, thus inhibiting the formation of "swift-trust".

Once pre-trust conditions are such that they favour the formation of a trust-based relationship, trust may form. The intensity of this relationship will depend on certain facilitators of trustworthiness, which have often been referred to loosely in the literature as antecedents (Mayer, et al., 1995), dimensions (Martins et al, 1997; Mishra, 1996; Robbins, 2001) or characteristics (Engelbrecht \& Cloete, 2000). In an attempt to clarify the role of these properties and introduce some degree of consistency, these will be referred to here as the facilitators of trustworthiness. The facilitators of trustworthiness are defined as those factors on which the trustor bases his or her evaluation of the trustworthiness of the trustee.

These factors have been inconsistently labelled in the literature as benevolence (Mayer et al., 1995), competency, openness, concern and reliability (Mishra, 1996) and integrity, competency, loyalty, openness (Robbins, 2001) amongst others (see Bews, 2000, p. 25-26). After considering the factors proposed in the literature, it is suggested that the following six facilitators of trustworthiness

- benevolence;

- competency;

- integrity;

- personality characteristics;

- a history of interactions; and;

- openness

cover most of what has been put forward and each of these facilitators is now briefly described.

Benevolence refers to the degree of concern that the trustee shows towards the trustor and how the trustor perceives the trustee to act in the trustor's interest. Mayer et al. (1996) indicate that benevolence incorporates support and encouragement and encompasses fairness, concern and loyalty. Competency concerns the ability of the trustee "...to have an influence in a specific domain" (Mayer et al., 1995, p. 717) which is to the benefit of the trustor (Davis, Mayer, \& Schoorman, 1995). Integrity refers to the consistent application of a set of moral and ethical principles which, according to McFall (Mayer et al., 1995, p. 719), should find acceptance by both trustor and trustee. Personality factors include those characteristics that have been referred to as the "Big Five" (Martins, 2000) and encompass agreeableness, conscientiousness, emotional stability, extroversion and resourcefulness. 
History of interactions refer to a " ...long-term pattern of exchanges" (Zucker in Husted, 1998, p. 237) or a collection of the trustor's experiences in respect of the trustee. Openness concerns a balanced sharing of information pertinent to the trustor-trustee relationship. Mishra (1996) advocates a balanced openness, pointing out that too much openness, particularly on a personal level, could be hurtful and may consequently damage a relationship.

\section{A model of trust}

It is proposed that once pre-trust conditions are favourable for the formation of trust, trust may initially be fixed at a particular point on a continuum before it either progresses or retreats along the continuum on the basis of the trustor's perception of the trustee's trustworthiness. In this regard, Lewicki and Bunker (1996) refer to "calculus-based", "knowledge-based" and "identification-based" trust.

Calculus-based trust is a form of trust based on the theory of deterrence and grounded in economics. At this level, trust functions largely on the hope that delivery will be rewarded and the fear that violation will be punished. Lewicki and Bunker $(1996$, p. 120) point out "...that at this stage, the deterrence elements will be a more dominant 'motivator' than the benefit-seeking elements". Robbins (2001) refers to deterrence-based trust, which is trust that is based on fear of reprisal in the event of the trust being violated.

Knowledge-based trust is grounded in predictability which is, in turn, based on knowledge gathered during regular interactions between trustor and trustee which usually extend over a period of time (Lewicki \& Bunker, 1996). In this manner the trustor is able to anticipate the trustee's actions and is more likely to rationalise certain inappropriate actions, thus allowing trust to withstand, what in different circumstances may be regarded as negative outcomes.

Identification-based trust is a form of trust dependent on a deep understanding of the needs of another and an " ...identification with the other's desires and intentions ... to the point that each can effectively act for the other" (Lewicki \& Bunker, 1996, p. 122). In this sense, identification-based trust is a form of trust where one party will protect and promote the interests of another, even in the other's absence, and is reciprocal in nature. At this level, trust is usually reserved for more intense relationships often seen within the family; however, this does not exclude trust from forming at this level in an employer-employee setting. Consider, for example, the relationships that exist between managers and secretaries, or amongst members of certain professional groups. Contracts are minimal at this level, in other words there is no need to monitor the other party's actions as loyalty is unquestionable at this level (Robbins, 2001).

The inter-play of the components of trust as discussed above is graphically illustrated in the model presented in figure 2 . Aspects of this model regarding the facilitators of trustworthiness were empirically examined in a study undertaken amongst the management and staff of a South African financial institution.

Based on this study, and in accordance with the brief discussion above of the suggested model of trust, the following hypotheses are formulated.

Hypothesis 1: There is a significantly positive linear relationship between the facilitators of trustworthiness listed as:

- openness;

- integrity;

- benevolence;

- competency;

- a history of interactions; and

- perceived personality characteristics

and interpersonal trust.

Hypothesis 2: Each facilitator will have a relative impact on the trustor's perceptions of the trustee's trustworthiness, the order of importance of which needs to be established.

\section{Figure 2: STAGES OF TRUST FORMATION}

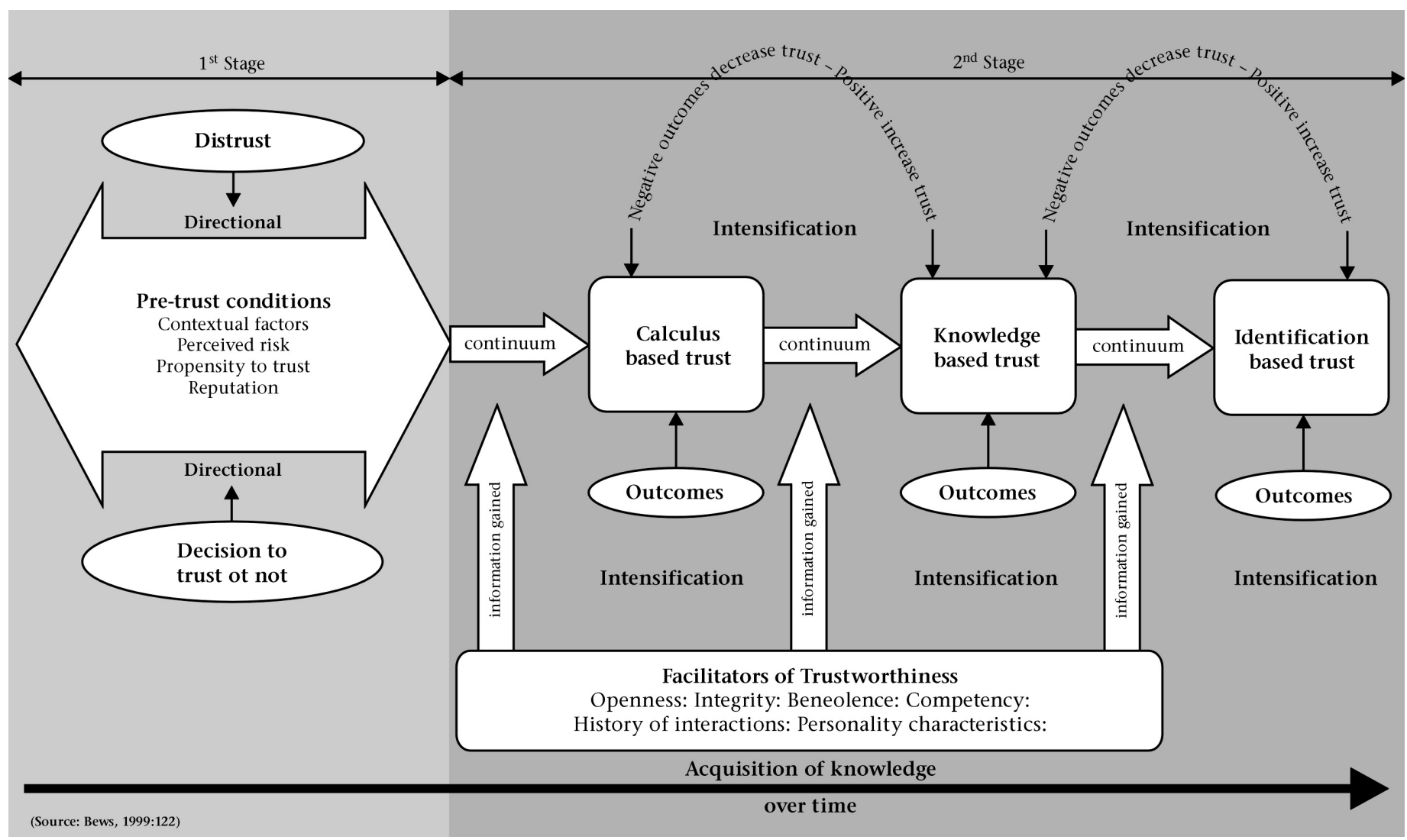




\section{METHOD}

A self-administered questionnaire designed to measure the facilitators of trustworthiness and interpersonal trust was developed and applied to the employees of a South African financial institution listed on the Johannesburg Stock Exchange.

\section{Sample}

At the time that the study was undertaken the company had 1216 employees dispersed throughout South Africa. Of these 907 responded to the survey, 897 in time to be included in the final analysis. This resulted in a response rate of $74 \%$. The population comprised both female $(56,4 \%)$ and male $(42,4 \%)$ respondents, the majority of whom $(95,1 \%)$ had been employed by the company for over one year. $95,5 \%$ of the population was over the age of 24 , with the majority $(31,2 \%)$ falling between the ages of 36 and 45 years. Most respondents had an education level above that of grade seven, with the majority (59\%) having obtained the equivalent of grade twelve. Most respondents were white (61\%) and either Afrikaans (26,3\%) or English (54,1\%) speaking.

\section{Procedure}

Self-administered questionnaires, together with covering letters explaining the survey as well as pre-addressed envelopes, were distributed to all members of staff. Staff were requested to complete this questionnaire, place it in and seal the envelope and return it to the researcher. Both distribution and collection of these questionnaires was done by means of the companies internal postal system. This phase of the project was completed within six weeks.

\section{Measuring instrument}

A 47-item questionnaire with a five-point Likert-type scale response format was developed and tested in various studies; the scale of trust developed and tested by Mayer et al. (1995) was used. A first and second order item analysis, together with a factor analysis, produced the following scales and levels of reliability. These scales are listed here together with two sample items from each scale:

\section{A1 - openness (Cronbach's $\alpha=\mathbf{0 , 8 8 3}$ )}

Communicates necessary information in an open and honest manner.

Tells our team the truth about change in the company.

A2 - integrity (Cronbach's $\alpha=0,836$ );

The morals and ethics (values) of the person to whom I report are of a high standard.

Is fair in judging performance.

A3 - benevolence (Cronbach's $\alpha=0,930$ );

Is supportive towards our team.

Is concerned about the welfare of our team.

A4 - $\quad$ competency (Cronbach's $\alpha=\mathbf{0 , 8 3 5 )}$;

Has a good knowledge of our business.

Is creative in on-the-job thinking.

A5 - $\quad$ personality factors (Cronbach's $\alpha=0,831$ );

Shows a high level of agreeableness (is co-operative \& courteous).

Is conscientious (hard working, with a propensity towards achievement).

A6 - history of interactions (Cronbach's $\alpha=0,719$ )

I have a good understanding of the person to whom I report.

The experiences I have had with respect to the person to whom I report have generally been positive.
B1 - trust (Cronbach's $\alpha=\mathbf{0 , 9 3 6 )}$

The person to whom I report is trustworthy. In a situation of risk our team can rely on the person to whom we report not to take advantage of our vulnerability.

\section{RESULTS}

Pearson's product-moment correlation coefficient (Statsoft, 2000) was calculated to establish the relationship between interpersonal trust and the facilitators of trustworthiness. As illustrated in table 1 , it was found that a high and significant ( $\mathrm{p}$ $<0,001)$ positive relationship existed between each of the facilitators of trustworthiness and interpersonal trust and consequently hypothesis 1 was confirmed.

TABLE 1

RELATIONSHIP BETWEEN INTERPERSONAL TRUST AND THE FACILITATORS OF TRUSTWORTHINESS

\begin{tabular}{lccccc}
\hline Model 6 & $\begin{array}{c}\text { Sum of } \\
\text { Squares }\end{array}$ & df & $\begin{array}{c}\text { Mean } \\
\text { Square }\end{array}$ & F & p-value \\
\hline Regression & 52942,0 & 6 & 8823,670 & 947,78 &, 000 \\
Residual & 6693,754 & 719 & 9,310 & & \\
Total & 59635,8 & 725 & & & \\
\hline
\end{tabular}

With the scatter plot indicating both homoscedasticity and linear regression, a step-wise linear regression procedure was used to determine the relationship between the facilitators of trustworthiness and interpersonal trust, the results of which are illustrated in table 2. In this way, it was established that, with an $\mathrm{R}^{2}$ value of 0,887 at step six, $88,7 \%$ of the variance in trust could be explained in the final step.

TABLE 2

CORRELATION BETWEEN THE FACILITATORS OF TRUSTWORTHINESS AND INTERPERSONAL TRUST

\begin{tabular}{llcc}
\hline Steps & Variables entered & R & Adjusted $\mathbf{R}^{2}$ \\
\hline 1 & A3 & 0,894 & 0,800 \\
2 & A3, A4 & 0,925 & 0,856 \\
3 & A3, A4, A2 & 0,934 & 0,872 \\
4 & A3, A4, A2, A6 & 0,939 & 0,880 \\
5 & A3, A4, A2, A6, A5 & 0,941 & 0,884 \\
6 & A3, A4, A2, A6, A5, A1 & 0,942 & 0,887 \\
\hline
\end{tabular}

To establish the relative importance of the facilitators of trustworthiness, a standard multiple regression was performed between all six facilitators of trustworthiness and interpersonal trust. In this way it was established that trust could be expressed as: Trust $=-2,552+0,689$, benevolence $+0,413$, competency $+0,356$, integrity $+0,438$, history of interactions $+0,252$, personality characteristics + 0,162 , openness, as table 3 illustrates. This confirms hypothesis 2 and establishes that, in respect of this study, benevolence is the most important predictor of trust, followed by competency; integrity; history of interactions and openness. 
TABLE 3

FACILITATORS OF TRUSTWORTHINESS AS PREDICTORS OF TRUST

\begin{tabular}{lccccc}
\hline \multicolumn{1}{c}{$\begin{array}{c}\text { Model } \\
6\end{array}$} & $\begin{array}{c}\text { Unstandardised } \\
\text { coefficient }\end{array}$ & $\begin{array}{c}\text { Standardised } \\
\text { coefficient }\end{array}$ & t & p-value \\
\hline & B & $\begin{array}{c}\text { std. } \\
\text { error }\end{array}$ & Beta & & \\
\hline (constants) & -2.552 & 0,615 & & $-4,147$ & 0,000 \\
A3 Benevolence & 0,689 & 0,056 & 0,342 & 12,218 & 0,000 \\
A4 Competence & 0,413 & 0,043 & 0,210 & 9,561 & 0,000 \\
A2 Integrity & 0,356 & 0,059 & 0,159 & 6,053 & 0,000 \\
$\begin{array}{l}\text { A6 History of } \\
\text { interactions }\end{array}$ & 0,438 & 0,078 & 0,116 & 5,513 & 0,000 \\
$\begin{array}{l}\text { A5 Personality } \\
\text { factors }\end{array}$ & 0,252 & 0,055 & 0,110 & 4,617 & 0,000 \\
A1 Openness & 0,162 & 0,073 & 0,108 & 4,411 & 0,000 \\
\hline
\end{tabular}

a) Dependent variable: Trust

These results must, however, be considered in the light of the limitations of multiple regression techniques which may point to certain relationships without indicating the causal mechanisms underlying these relationships (Statsoft, 2000).

\section{DISCUSSION}

In this study, it was found that there was a statistically significant and positive relationship between the facilitators of trustworthiness and interpersonal trust and that benevolence presented as the strongest predictor of trust followed by competency, integrity, history of interactions, personality characteristics and openness. Although it may seem that openness should play a stronger role in the formation of trust, this role may in fact be limited. As Mishra (1996) points out, openness beyond a certain level may in fact be counterproductive as it could be hurtful and may consequently damage a relationship.

The study undertaken by Martins (2000) supports the positive relationship found between the personality characteristics (agreeableness and conscientiousness) and interpersonal trust. Both agreeableness and conscientiousness appear to be significant manifestations of trust.

Aspects of this study appear to support certain of the assumptions of Mayer et. al. (1995) and Mishra (1996) and confirm aspects of the findings of Engelbrecht and Cloete (2000). Both Mayer et. al. and Mishra. highlight the importance of benevolence in the facilitation of trustworthiness. Engelbrecht and Cloete (2000, p. 26), on testing the integrated model of trust of Mayer et. al. (1995), found that a "[h]igh and significant $(\mathrm{p}<0,01)$ positive relationship exists between interpersonal trust and each of the factors of trustworthiness (ability: $\mathrm{r}=0,77$; benevolence: $\mathrm{r}=0,88$; integrity: $\mathrm{r}=0,92$ )", findings that are similar to those in this study.

While benevolence and integrity are similar constructs both the model of Mayer et al. (1995) and this study, competency, as used here, although closely approaching the construct "ability" in Mayer et al. (1995), includes both a technical and people management component. Engelbrecht and Cloete (2000, p. 26) found that "[o]nly the regression coefficients of integrity and benevolence differed significantly from zero...", while in this study it was found that all six facilitators of trustworthiness differed significantly from zero. It is possible that by including a people management component in competency, as was done in this study, competency was more inclined to address what the trustee could do for the trustor. The trustor's perceptions of what the trustee is able to do for the trustor is, according to Davis et. al. (1995, p. 11-12), an important component of trust.

Engelbrecht and Cloete (2000, p. 26) point out that it appears that " ...the relationship between interpersonal trust and ability is a direct result of the relationship between benevolence, integrity and trust." This is probably true where ability possibly relates to technical ability, which is the case in the model of Mayer et al. (1995). However, the inclusion of a people management component probably changes this relationship and possibly explains the difference in the results of this study compared with those of Engelbrecht and Cloete in respect of ability and competency.

Whereas Engelbrecht and Cloete (2000, p. 26) found that a combination of ability, integrity and benevolence explained $86 \%$ of the variance in trust, the findings of this study are that a combination of benevolence, competency and integrity explained $87.2 \%$ of the variance in trust. This slight difference between the findings of the two studies is possibly due to the difference between ability as applied by Mayer et al. (1995) and competency as used in this study. Notwithstanding the limitations of multiple regressions (Statsoft, 2000), which must constantly be kept in mind, both Engelbrecht and Cloete's (2000) study and the results of this study seem to indicate some support for accepting certain facilitators as essential to the development of intra-organisational trust.

Although only aspects of what was a much broader study are reported on here, it is clear from this broader study that there are many issues in respect of trust that need to be empirically tested before any clear understanding of the dynamics of trust will emerge. For instance, one of the salient points was that management and/or leadership styles appear to play an important role in the unfolding of trust, an issue that may merit further attention. In times of change and instability, people turn to personal relationships for stability and the quality of these relationships are largely determined by trust (Robbins, 2001).

It is also necessary to revisit and refine the model of trust discussed above. Other aspects of this model which need to be empirically tested are the relationship of the pre-trust conditions and any impact that they may have on a decision to trust; how trust may be fixed at a certain level on a continuum; and in terms of this, what type of relationship may be fixed at what level on the continuum. Finally, in respect of the measuring tool that was used in this study, this instrument will need to be reconsidered and modified in the light of the experiences gained during the study.

\section{REFERENCES}

Bell, D. (1973). The coming of post-industrial society: a venture in social forecasting. New York: Basic Books.

Burt, R.S., \& Knez, M. (1996). "Trust and third-party gossip." In Kramer, R. M., \& Tyler, T. R. (Eds.). Trust in organizations: Frontiers of theory and research. Thousand Oaks, CA: Sage.

Bews, N.F. (1999). A sociological analysis of the concepts "postindustrial" and "post-modern" and their effects on the notion of employer-employee trust. Unpublished MA dissertation, Johannesburg: Rand Afrikaans University.

Bews, N.F. (2000). An investigation into the facilitators of the trustworthiness of managers. Unpublished Doctoral thesis, Johannesburg: Rand Afrikaans University.

Brenkert, G.G. (1998a). Trust, business and business ethics: an introduction. Business Ethics Quarterly. 8 (2): 195-203.

Brenkert, G.G. (1998b). Trust, morality and international business. Business Ethics Quarterly. 8 (2):293-317.

Crandall, N. F., \& Wallace, M. J. (1998). Work and rewards in the virtual workplace: A new deal for employers and employees. New York: American Management Association. 
Creed, D.W.E., \& Miles, R.E. (1996). "Trust in organisations. A conceptual framework linking organizational forms, managing philosophies, and the opportunity costs of controls." In Kramer, R.M., \& Tyler, T.R. (Eds.) Trust in organizations: frontiers of theory and research. Thousand Oaks, CA: Sage.

Darley. J. (1998). Trust in organisations: Frontiers of theory and research. Business Ethics Quarterly. 8 (2): 319-335.

Davis, J.H., Mayer, R.C., \& Schoorman, F.D. (1995). The trusted general manager and firm performance: empirical evidence of a strategic advantage. Paper presented at the Annual Meeting of the Strategic Management Society, Mexico City.

Dibben, M.R. (2000). Exploring interpersonal trust in the entrepreneurial venture. London: MacMillan Press.

Engelbrecht, A.S. \& Cloete, B.E. (2000). An analysis of a supervisor-subordinate trust relationship. Journal of Industrial Psychology, 26 (1), 29-38.

Flores, F., \& Solomon, R.C. (1998). Creating trust. Business Ethics Quarterly. 8 (2): 205-232.

Handy C.B. (1994). The age of paradox. Boston: Harvard Business School Press.

Hiltrop, J. (1995). The changing psychological contract: The human resource challenge of the 1990's. European Management Journal, September. 13: 286-94.

Horton, R.T., \& Reid, P.C. (1991). Beyond the trust gap forging a new partnership between managers and their employers. Homewood, Ill: Business One Irwin.

Howard, A. (Ed.) (1996). The changing nature of work. San Francisco: Jossey-Bass Publishers.

Husted, B.W. (1998). The ethical limits of trust in business relations. Business Ethics Quarterly. 8 (2): 233-248.

Jones, T.M., \& Bowie, N.E. (1998). Moral hazards on the road to the "virtual" corporation. Business Ethics Quarterly. 8 (2): 273-292.
Kramer, R.M., \& Tyler, T.R.(Eds.) (1996). Trust in organizations: Frontiers of theory and research. Thousand Oaks, CA: Sage.

Kreitner, R.S., \& Kinichi, A. (1998). Organisational behaviour. Boston: McGraw-Hill: Irwin.

Lewicki, R.J. \& Bunker, B.B. (1996). Developing and maintaining trust in work relationships. In R.M. Kramer \& T.R. Tyler, (Eds.). Trust in organizations: frontiers of theory and research. Thousand Oaks, CA: Sage.

Martins, N. (2000). Developing a trust model for assisting management during change. Journal of Industrial Psychology. 26 (3): 27-31.

Mayer, R.C., Davis, J.H., \& Schoorman, F.D. (1995). An integrative model of organizational trust. Academy of Management Review. 20 (3): 709-734.

Masuda, Y. (1981). The information society as post-industrial society. Washington, D. C.: World Future Society.

Meyerson, D., Weick, K.E., \& Kramer, R.M. (1996). "Swift trust and temporary groups." In R.M. Kramer, \& T.R. Tyler, (Eds.) Trust in organizations: Frontiers of theory and research. Thousand Oaks, CA: Sage.

Mishra, A.K. (1996). Organizational responses to crisis: The centrality of trust. In R.M. Kramer, \& T.R. Tyler, (Eds.). Trust in organizations: Frontiers of theory and research. Thousand Oaks, CA: Sage.

Powell, W.W. (1996). "Trust-based forms of governance." In R.M. Kramer, \& T.R. Tyler, (Eds.). Trust in organizations: Frontiers of theory and Research. Thousand Oaks, CA: Sage.

Robbins, S.P. (2001). Organisational behaviour. Upper Saddle River, Prentice Hall: NJ.

Soule, E. (1998). Trust and managerial responsibility. Business Ethics Quarterly. 8 (2): 249-272.

Statsoft. (2000). Electronic statistics textbook. http://www.statsoft.com/ textbook/stmulreg.html (05/06/2000) 


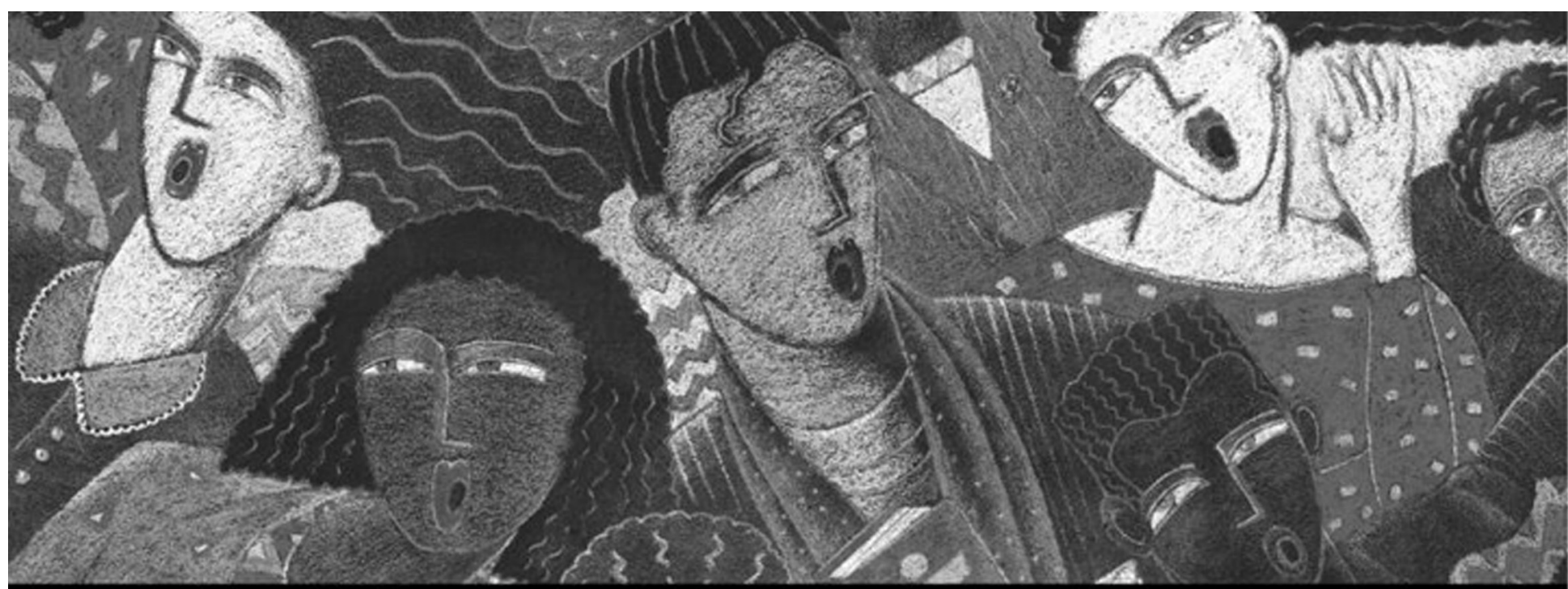

IN A CHANGING WORLD OF WORK EVERYONE NEEDS A PARTNER THEY CAN TRUST.

\section{A partner ...}

... who provides practical, integrated solutions to your business challenges.

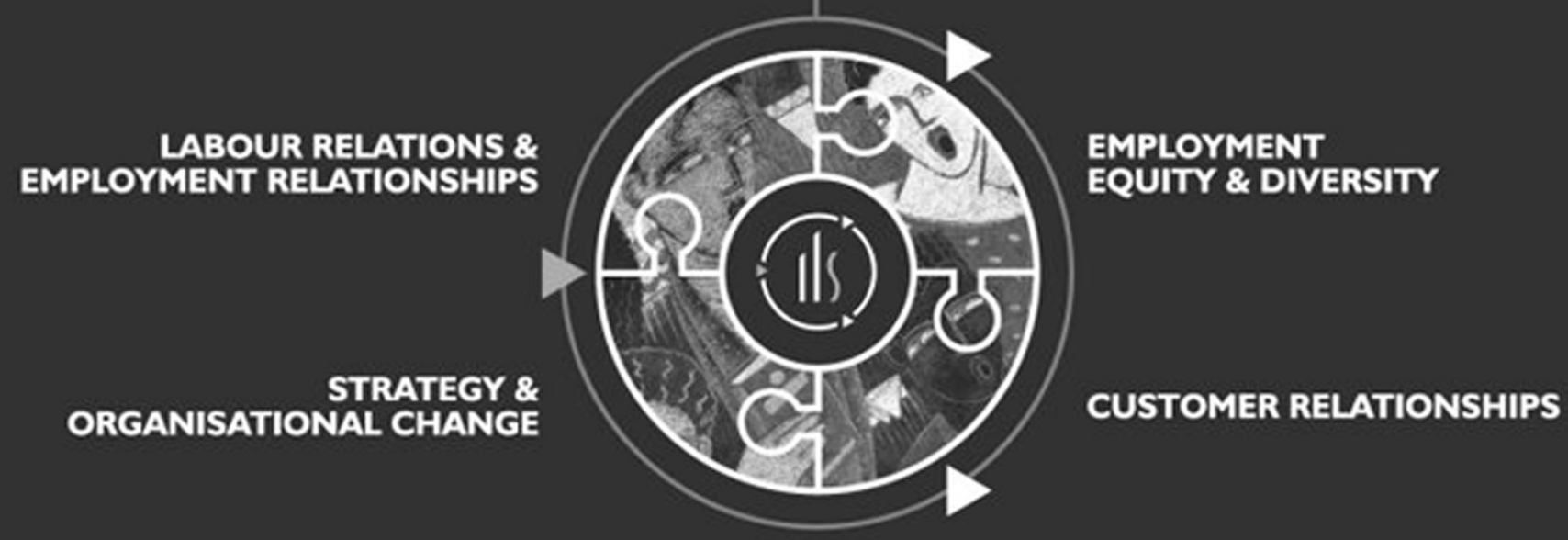

A partner ...

... who understands that we live in an ever-changing world of challenge and opportunity.

... who customises world class solutions, tools and change processes to suit local issues and needs.

... who understands that building productive working relationships is all about people - employees as well as Customers.

... who you can build a long term relationship with.

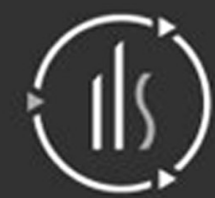

- integrated labour solutions

consulting - training - facilitation - audits - research $\cdot$ employment practice liability insurance

For more information on Integrated Labour Solutions visit our website on www.ils-sa.com or e-mail us at ils@ils-sa.com.

Randburg Tel (0I I) 3260680 • Cape Town Tel (021) 4623933 • Eastern Cape Tel (041) 3736090 • Boland Tel (023) 3475532 